\title{
Strategi Implementasi Profesionalisme Guru pada Masa Pandemi di MI Hikmatun Najah
}

\author{
Partono \\ IAIN Kudus, Kudus, Indonesia \\ partono@iainkudus.ac.id
}

\begin{abstract}
The purpose of this study is to find out about the efforts or strategies for implementing teacher professionalism during the pandemic because learning activities are no longer carried out face-to-face but are completely digital / online. This type of research is field research with a descriptive qualitative approach that tries to explore the meaning of teacher professionalism as a step to develop the quality of educational institutions while still adjusting educational goals. The results of this study indicate that the majority of MI Hikmatun Najah teachers can implement their professionalism through online learning properly and right. They still carry out their duties and obligations in a professional manner even though the learning process is online / online. This research also shows that teachers can put their professionalism in accordance with the place and conditions.
\end{abstract}

Keywords: Implementation; Teacher Professionalism; Pandemic

\begin{abstract}
Abstrak
Tujuan penelitian ini adalah untuk mengetahui tentang upaya-upaya atau strategi implementasi profesionalisme guru pada masa pandemi dikarenakan kegiatan pembelajaran tidak lagi dilakukan dengan tatap muka melainkan dengan serba digital/online. Jenis penelitian ini adalah penelitian lapangan dengan pendekatan kualitatif deskriptif yang mencoba mengeksplorasi makna profesionalisme guru sebagai langkah mengembangkan mutu lembaga pendidikan dengan tetap menyesuaikan tujuan pendidikan.. Hasil penelitian ini menunjukan bahwa mayoritas guru MI Hikmatun Najah dapat mengimplementasikan sikap profesionalisme mereka melalui pembelajaran online dengan baik dan tepat. Mereka tetap melaksanakan tugas dan kewajiban mereka secara profesional walaupun proses pembelajaran melalui online/daring. Penelitian ini juga menunjukkan bahwa para guru dapat menempatkan sikap profesionalisme mereka sesuai dengan tempat dan kondisi.
\end{abstract}

Kata kunci: Implementasi; Profesionalisme Guru; Pandemi 


\section{A. Pendahuluan}

Guru merupakan salah satu komponen penting dalam manajemen pendidikan. Karena guru sangat berpengaruh dalam proses pembelajaran di kelas, terutama bagi peserta didik. Oleh karena itu, guru dituntut untuk bersikap profesional. Namun pada kenyataanya, masih banyak guru yang bersikap ala kadarnya. Guru juga berperan dalam menentukan masa depan bangsa ini. Jika seorang guru tidak berkualitas maka murid yang dihasilkan akan menjadi lulusan yang lemah. Namun di masa pandemi COVID 19 sekarang ini, seluruh warga negara Indonesia diharuskan untuk bekerja, belajar dan beribadah dari rumah. Dengan demikian, seluruh proses belajar-mengajar yang awalnya melalui proses tatap muka dialihkan ke pembelajaran online.

Pembelajaran online/daring merupakan hal baru bagi kita, pastinya akan terasa asing dan sulit bagi para guru maupun siswa-siswanya untuk menyesuaikan diri. Akan tetapi hal tersebut tidak kemudian melemahkan guru dan siswa untuk tetap harus belajar dan optimis melalui semua problem system pembelajaran baru ini (Partono, 2020). Semua pembelajaran beralih ke online, baik menggunakan aplikasi whatsApp, google classroom maupun televisi. Oleh karena itu, hal tersebut mewajibkan guru untuk tetap mengimplementasikan sikap profesionalisme mereka sebagai seorang guru melalui pembelajaran online. Karena mengingat sangat pentingnya sikap profesional tersebut, dalam pepatah jawa mengatakan bahwa guru itu digugu lan ditiru baik sikap maupun perkataannya oleh para anak didiknya. Jadi, sudah seharusnya jika seorang guru bersikap profesional walaupun melalui pembelajaran online tersebut. Lantas bagaimana caranya seorang guru mengimplementasikan sikap profesionalisme mereka dalam pembelajaran online.

Oleh karena itu, untuk mendukung program pemerintah dalam mengembangkan kompetensi guru, maka guru harus meningkatkan kemampuannya menggunakan teknologi dalam pembelajaran online. Bagaimana guru menyampaikan pengetahuan harus dirancang dengan strategi yang matang serta tidak asal asalan. Mengingat kreatifitas dan keinovatifan guru sangat diperlukan dalam proses mengajar (transfer pengetahuan), supaya murid bisa tertarik dalam menyimak materi pembelajaran online. Guru harus bisa melepaskkan sistem pembelajaran disekolah dengan menggunakan tidak hanya metode ceramah yang terkesan kaku. Perlu diketahui bahwa dalam pembelajaran online guru dituntut untuk menciptakan terobosan dan metode serta media baru agar siswa tidak bosan terhadap pembelajaran online yang disampaikan. Sebagaimana diketahui bersama bahwa dalam pembelajaran online siswa mempunyai berbagai godaan yang mampu mengalihkan perhatian siswa. Saat pembelajaran online siswa menggunakan handphone maupun laptop didukung dengan aplikasi dan situs online yang dapat mengalihkan perhatian siswa saat belajar online. Kondisi teresebut 
pastinya menjadi salah satu tuntutan bagi keprofesionalan guru untuk menciptakan daya tarik yang lebih dalam pembelajaran online.

Pelaksanaan dan perjalanan pembelajaran online yang menuntut guru untuk lebih kreatif dan inovatif, suatu masalah yang ada pada saat ini yaitu masih banyak guru yang gagap teknologi, sedangkan teknologi menjadi media utama dalam pembelajaran online. Di Indonesia masih banyak guru yang belum menguasai teknologi. Walaupun guru telah melalui proses setifikasi, nyatanya masih ada guru yang belum bisa menguasai teknologi secara efektif. Terlebih jika guru yang belum mendapatkan sertifikasi, bisa dipastiakan sebagian guru yang belum melalui proses sertifikasi belum menguasai teknologi guna mendukung proses pembelajran online.

Masalah lain yang lebih berat dalam pebelajaran online yaitu bagaimana guru mendidik siswa dalam proses pembelajaran online. Dalam pendidikan guru tidak hanya berperan sebagai pengajar dan pentransfer pengetahuan. Tetapi guru juga berkewajiban untuk menjadi pendidik agar siswa memiliki kepribadian yang baik dan terhindar dari dekadensi moral. Dalam pembelajaran online apakah guru mampu melaksanakan tugasnya dalam mendidik siswa bisa dikatakan sangat sulit. Dalam pembelajaran online guru tidak bisa mendidik sisiwa secara langsung. Sehinngga guru kesulitan dalam mencontohkan perilaku yang bisa dijadikan tauladan. perjalanan pembelajaran online guru mendidik murid melalui aplikasi yang digunakan sebagai media. Bagi guru yang belum menguasai tehknologi tentunya ini mennjadi kesulitan tersendidiri bagi guru tersebut. Hal ini bisa dilihat bagaimana guru bisa mendidik sisiwa melalui pembelajaran online sedangkan teknologi sebagai media pembelajaran online belum dikuasai.

Selain masalah penguasaan teknologi, manajemen pembelajaran yang di implementasikan guru dalam pembelajaran online sangat mencerminkan keprofesionalan seorang guru. Masih banyak guru yang pasif dalam proses pembelajaran online. Guru hanya memberikan materi dan tugas lewat e-mail, setelah itu dikumpulkan. Sistem pembelajaran seperti ini mengakitkan siswa bosan terhadap pelajaran tersebut. Jika hal ini sudah terjadi, kecil kemungkinan siswa untuk bisa mendapatkan pengetahuan dari proses pembelajaran online tersebut. Apalagi harapan agar siswa bisa mendapatkan pelajaran nilai moral, hal tersebut sangat tidak mungkin. Dalam proses pembelajaran seperti itu, dapat mencerminkan bagaimana tingkat profesionalitas seorang guru dalam pembelajaran online.

Menurut UU No. 14 Tahun 2005, kata profesional berarti suatu pekerjaan atau kegiatan yang dilakukan oleh seseorang dan menjadi sumber penghasilan kehidupan yang memerlukan keahlian, kemahiran, atau kecakapan yang memenuhi standar mutu atau norma tertentu serta memerlukan pendidikan profesi(Sudarwan, 2012). Sedangkan 
istilah profesionalisme mempunyai arti suatu tingkah laku, tujuan, maupun rangkaian yang menggambarkan profesi.(Suprihatiningrum, 2013) Jadi, sudah dapat diketahui bahwa sikap profesionalisme guru merupakan suatu sikap atau tingkah laku yang menggambarkan bagaimana kemahiran seseorang menjadi guru. Namun, bukan hanya itu pengertian dari sikap profesionalisme seorang guru. Masih banyak lagi sikap-sikap profesionalisme yang harus diketahui dan di implementasikan seorang guru. Sikap profesionalisme seorang guru sangatlah penting, jadi jangan pernah menganggap remeh tentang hal ini.

Zaman yang semakin canggih dan terus berkembang ini. Teknologi informasi sekarang merupakan kebutuhan primer bagi manusia. Karena, hidup di zaman modernisasi ini mengharuskan kita untuk berkecimpung di dunia maya yang membutuhkan internet. Pembelajaran online salah satu contohnya, karena dunia sedang dalam masa yang tidak baik dikarenakan adanya masalah terkait COVID 19. Pemerintah menetapkan peraturan untuk semua sekolah termasuk MI Hikmatun Najah Dologan Kecamatan Japah Kabupaten Blora ditutup dan proses kegiatan belajar mengajar dialihkan di rumah siswa masing-masing melalui online. Para guru dan siswa otomatis dituntut untuk mengenal dan menguasai internet. Mungkin bagi para orang tua siswa yang sudah berumur dan tidak mengetahui apa itu pembelajaran online akan merasa kesulitan. Selain itu, para guru yang sudah tidak muda lagi pun akan ikut merasa kesulitan. Oleh karena itu, mereka harus mengetahui apa itu pembelajaran online.

Berdasarkan penjelasan tersebut menimbulkan pertanyaan bagaimanakah mengimplementasikan sikap profesionalisme guru MI Hikmatun Najah dengan diberlakukannya pembelajaran online pada masa pandemic covid-19. Mengingat pembelajaran online merupakan suatu hal baru dalam proses pendidikan di negara kita. Disini saya menngunakan jenis penelitian kualitatif deskriptif. Dalam menggunakan jenis penelitian ini, penili harus menggunakan teori yang lebih banyak dan harus sesuai dengan fenomena yang sedang berkembang dalam masyarakat. Peneliti kualitatif harus dapat menggali data berdasarkan apa yang diucapkan, dirasakan dan dilakukan oleh partisipan atau sumber data. Oleh karena itu, disini peneliti akan melakukan observasi maupun wawancara secara langsung dengan guru yang mengikuti proses kegiatan belajar mengajar secara online. Metode analisis data dilakukan dengan cara menelaah, mereduksi, menyajikan data, dan verifikasi data guna untuk mengambil kesimpulan. 


\section{B. Pembahasan}

\section{Profesionalisme Guru}

Profesionalisme berasal dari kata profesi yang mempunyai arti seseorang yang akan menekuni suatu bidang pekerjaan. Selain itu, kata profesi juga mempunyai arti sebagai sebuah pengetahuan dan ketrampilan tertentu yang bersumber dari pendidik yang akademis intensif yang menjadi persyaratan dalam suatu jabatan atau pekerjaan tertentu. Secara etimologi profesi berasal dari kata bahasa Inggris yaitu profession atau berasal dari bahasa latin profecus yang mempunyai arti mengakui, mayatakan mampu atau ahli dalam melakukan suatu bidang pekerjaan. Adapun secara terminologi, profesi merupakan suatu pekerjaan yang orangnya disyaratkan harus berpendidikan tinggi dan ditekankan pada pekerjaan mental.(Kusnandar, 2007).

Sedangkan profesionalisme sendiri juga mempunyai arti yaitu, suatu pandangan yang menyatakan bahwa suatu pekerjaan tertentu yang keahliaanya hanya bisa bersumber dari pendidikan dan latihan khusus. Seseorang yang mempunyai sifat profesional, maka secara tidak langsung akan selalu meningkatkan mutu kualitas dirinya, dangan melalui cara pendidikan dan latihan.(Tilaar, 2002).

Guru merupakan komponen yang paling utama dalam bidang pendidikan sudah menjadi pemegang peranan penting dalam sisi perencanaan, pelaksanaan maupun pengembangan sebuah kurikulum. Guru yang merupakan peranan penting dalam bidang pendidikan, maka guru harus aktif dan mampu menempatkan posisinya sebagai tenaga kerja yang profesional, dan menyesuaikan dengan apa yang sudah dituntut oleh masayarakat yang semakin berkembang di masa pandemi ini. Guru juga berperan sebagai pengajar dan pendidik anak-anak di dalam lembaga pendidikan atau formal. Dengan hal ini, kaitannya dengan profesi guru adalah sebagai seorang guru harus mempunyai pengetahuan, pengalaman, ketrampilan dan ketelatenan untuk mengajarkan anak dan membentuk anak supaya menjadi anak yang memliki sikap yang baik dan sesuai dengan harapan.(Martitnis Yamin, 2007).

Jadi, penjelasan dari kata guru adalah orang dewasa yang mampu mengajar, membiming dan mendidik seorang siswa atau peserta didik serta sadar akan tanggung jawabnya di dalam bidang pendidikan. Guru juga harus mampu merancang program pembelajaran serta mampu mengelola peserta didik dalam kelas agar peserta didik dapat belajar dengan baik dan tertib. (Martitnis Yamin, 2007).

Dengan demikian, profesionalisme guru merupakan kondisi kualitas seorang guru dalam keahliannya mengajar peserta didik di lembaga pendidikan. Atau dengan kata lain yaitu, guru profesional adalah orang yang terdidik dan mampu melaksanakan 
tugas dan kewajibannya seorang guru yang maksimal dalam lembaga pendidikan, serta terlatih dan juga mempunyai banyak pengalaman di bidang apapun khususnya dibidang pendidikan(Kusnandar, 2007).

\section{Hakekat Profesi Guru}

Guru adalah sebuah profesi, yang mempunyai makna sebuah profesi yang tidak bisa dilakukan oleh sembarang orang diluar bidang pendidikan dan juga mempunyai keahlian khusus dalam menjadi seorang guru. Profesi adalah suatu jabatan, profesional adalah kemampuan atau keahlian dalam memegang suatu jabatan tertentu, sedangkan profesionalisme adalah jiwa dari suatu profesi dan profesional. Berikut tiga garis besar sikap profesional seorang guru. Guru yang profesional harus dapat menguasai bidang-bidang ilmu yang akan diajarkan dengan baik. Ia harus benar-benar ahli dan dapat menguasai bidang pendidikan yang ia ajarkan. Selanjutnya, karena zaman yang selalu berkembang, seorang guru juga harus ikut serta meningkatkan dan mengembangkan ilmu yang diajarkannya. Dengan melakukan penelitian yang terus menerus menggunakan berbagai macam metode seorang guru dapat meningkatkan dan mengembangkan ilmunya.

Inti kegiatan belajar mengajar, seorang guru bukan hanya menyampaikan pengetahuan (transfer of knowledge) kepada murid, namun dalam mendidik guru juga harus menyampaikan nilai moral (transfer of value). Sementara itu dalam menstransfer kemampuan atau skill, guru harus memberikan berbagai keterampilan yang dapat mengembangkan skill murid. Karena untuk mencapai kata profesional, guru dituntut mampu membentuk murid tidak hanya di pengetahuan saja, namun juga berbagai bidang yang berkaitan dengan dunia pendidikan lainnya. Selain itu, dalam tugasnya saat proses pembelajaran guru harus mencerminkan profesionalitasnya. Profesionalitas guru tersebut harus bisa dibuktikan melalui kompotensi yang dimilikinya. Tentunya kompetensi yang dimilikinya tersebut juga harus diimplementasikan secara maksimal.

Guru yang profesional harus mampu menyampaikan ilmu (transfer of knowledge) yang dimilikinya kepeda peserta didiknya secara efektif dan efesien. Guna menunjangnya, seorang guru harus memiliki ilmu keperguruan terlebih dahulu. Karena jika seorang guru sudah memiliki bekal ilmu keperguruan, akan mempermudahkan ia dalam menyampaikan ilmu. Guru yang profesional harus memegang teguh kode etik profesi guru. Kode etik ini ditekankan pada akhlak mulia. Karena, seorang guru adalah panutan, contoh dan teladan bagi murid-murid mereka. Dengan begitu, ilmu yang telah mereka ajarkan akan didengarkan dan dilaksanakan oleh murid-murid mereka. Sebagai pendidik yang profesional, seorang guru tidak cukup hanya menguasai bahan pelajaran saja, namun seorang guru juga harus tahu nilai-nilai apa saja yang dapat diserap atau 
diterima oleh murid-murid mereka. Selain itu, sifat-sifat kepribadian apa yang dapat diterima pertumbuhannya melalui materi pelajaran yang diajarkan (Abuddin Nata, 2012).

Seiring dengan kemajuan zaman dan munculnya teknologi informasi yang telah berkembang pesat di masa pandemi ini, guru harus mampu bersikap sebagai motifator, fasilitator dan pembimbing yang baik peserta didik dan juga bisa memberi kesempatan kepada peserta didik untuk mengelola dan mencari sumber informasi sendiri. Keahlian/kompetensi guru harus dikembangkan bukan hanya berdasarkan dengan prinsip mengajar saja, karena sekarang guru tidak bertidak sebagai penyaji informasi saja.(Uzer, 2006).

\section{Tantangan Profesionalisme Guru di Masa Pandemi}

Pada abad 21 ini profesi guru yang sudah dipengaruhi oleh penggunaan teknologi informasi yang telah ditandai dengan masa serba digital ini. Guru yang tidak hanya memiliki kepribadian akhlak yang baik guru juga harus mampu mengolah atau mengelola sumber-sumber informasi yang semakin meningkat di masa ini selain guru wajib mampu menyampaikan informasi dengan cara metodologis pada saat mengajar peserta didik di sekolah maupun diluar sekolah, semua itu adalah tututan seorang guru unutk meningkatkan professiinalisme guru di masa pandemi ini (Hanik, 2020).

Akan tetapi realitanya saat ini tidak seimbang antara meningkatnya teknologi informasi yang semakin cepat dengan keadaan guru terhadap peserta didik, terutama di lingkungan masyarakat, sehingga hal tersebut sering membuat guru menjadi tertinggal jauh di belakang. Ketika masyarakat memasuki era digital yang informasinya mencakup tentang informasi dan pengetahuan sedangkan dari gurunya sendiri malah ketinggalan, seperti ketika seorang guru telah beruasaha mencoba merubah dirinya dengan menyesuaikan zamannya sudah maju ini, akan tetapi perubahan guru tersebut masih lebih maju dari perkembangan zaman yang semakin modern ini, otomtis guru tersebut masih kalah dalam langkah. Dengan demikian guru tersebut masih dinyatakan ketinggalan zaman (Putri \& Nugroho, 2016).

Masa pandemi ini siswa dalam jumlah besar dapat dibelajarkan oleh guru dengan kemampuan artifisialnya. Guru tidak hanya mempunyai tugas mengurus peserta didik yang ada di kelas, akan tetapi guru juga mempunyai tugas dapat membelajarkan jutaan peserta didik di "kelas dunia" dengan memebri pelayanan terhadap peserta didik secara individu pada waktu yang bersamaan. Sehingga dengan adanya teknologi informasi internet, ilmu pengetahuan dapat diterima dengan dengan mudah dan cepat, 
sehingga ilmu pengetahuan tersebut juga dapat bermanfaat bagi peserta didik di masa pandemi ini (Ranak Lince, 2016).

Situasi saat ini, akan mempengaruhi guru pada apa yang ia kerjakan dan kebiasaan yang selama ini guru kerjakan. Karena setiap orang akan memperoleh ilmu pengetahuan dengan mudah cara melalui sarana " internet" dan "teknologi informasi" dan ilmu pengetahuan akan menyebar kemana- mana di seluruh dunia (Mu'ayyadah \& Fatmawati, 2021). Konsep dasar yang sudah dikenal dengan distribusi kecerdasan (distribusi pengetahuan) dalam paradigma ini, tenaga kerja dan lembaga pendidikan yang semuanya akan akan berpindah posisi yang berawal dari sumber informasi tentang ilmu pengetahuan menjadi "mediator" terhadap peserta didik dalam bidang ilmu pengetahuan. Jadi, dalam paradigma yang ada di Indonesia guru berkualitas adalah guru yang dapat memenuhi kompetensi profesional padegogik, personal serta sosial. Karakteristik ini merupakan pola dalam pendidikan yang mana ideology bangsa, tujuan pembangunan serta konsep pendidikan universal sudah menjadi bahan pertimbangannya (Akcaoglu \& Koehler, 2014).

Teradapat 7 tantangan guru di abad 21 (era digital), Mengajar dan membimingi di lingkungan yang amsayarakatnya memiliki keberagaman budaya dengan menggunakan kompetensi mutu bahasa. Mengajar dan membimbing masyarakat untuk membangun makna (konsep). Mengajar masayarakat untuk aktif dalam belajar mengajar dan teknologi. Mengajarkan dengan pengalaman dan pengetahuan baru yang mengenai tentang kamapuan mengajar dan akuntabilitas(Ahmad Susanto, 2016).

Konsenkuensi dan munculnya era digital atau masa pandemi ini akan mempengaruhi peserta didik dalam kegiatan belajarnya, seperti perpustakaan dan fasilitas-fasilitas yang ada di sekolah yang berupa internet (teknologi informasi). Ketika sekolahan dalam kondisi yang sangat memprihatinkan, seperti perpustakaan yang di dalamnya terdapat keterbatasan buku dan compact disc (CD) atau bahkan ada buku yang sudah kedaluarsa, sebagai tenaga pendidik kita tidak perlu sedih, dengan melihat kondisi seperti sebagai seorang tenaga pendidik harus bisa berfikir kreatif dan inovatif untuk menghadapi masalah tersebut agar proses pembelajaran dalam lembaga pendidikan dapat berjalan dengan lancar. Tantangan seperti itu merupakan tantangan yang cukup berat yang harus dihadapi oleh lembaga pendidikan, oleh karena itu tenaga kerja harus pandai menggunakan strategi yang tepat dan baik untuk menyelesaikannya (Mudhofir, 2012). 


\section{Strategi Pengembangan Profesionalisme Guru MI Hikmatun Najah di Masa Pandemi}

Pengembangan profesionalisme guru sekarang menjadi pusat perhatian global, karena guru berperan tidak hanya meberikan informasi-informasi mengenai tentang teknologi informasi serta ilmu pengetahuan, akan tetapi guru juga mempunyai tugas dan peran sendiri yang berguna untuk menciptakan jiwa dan sikap yang mampu bertahan dalam masa pandemi ini. Guru bertugas dan berperan sebagai seseorang yang dapat membantu peserta didik agar siap untuk menghadapi tantangan yang terjadi di masa pandemi ini serta dorongan yang telah berkembang dalam diri peserta didik.

Pengelolaan peserta didik dalam bidang pendidikan meliputi, aspek-aspek kepribadian terutama aspek intelektual, sosial, emosional dan ketrampilan. Tugas mulia ini tidak hanya guru yang bertindak untuk mempersiapkan generasi muda untuk memasuki masa pandemi ini, akan tetapi harus mempersiapkan diri untuk tetap eksis, baik sebagai individu maupun sebagai profesional. Mengembangkan profesionalisme guru tidak sesuatu hal yang mudah, melainkan dipengaruhi oleh beberapa faktor. Oleh karena pengamatan dalam lingkungan merupakan suatu kegiatan yang penting untuk dilakukan guna untuk pengembangan, dan khususnya apabila faktor tersebut dapat menghalangi proses perkembangan profesi guru tersebut. Kaitannya yaitu terletak dalam faktor birokrasi, terutama birokrasi pendidikan yang biasanya tidak mendukung dengan adanya perkembangan profesionalisme guru di masa pandemi ini (Mustofa, 2007). Beberapa informasi terkait pengimplementasian terhadap sikap profesionalisme seorang guru MI Hikmatun Najah melalui pembelajaran online berdasarkan hasil wawancara dan observasi

Guru mengirim kegiatan melalui grup kelas secara tepat waktu. Hal ini menunjukkan sikap profesionalisme guru yaitu Guru yang profesional harus mampu menyampaikan ilmu (transfer of knowledge) yang dimilikinya kepeda peserta didiknya secara efektif dan efesien (Zafi \& Partono, 2020). Dengan mengirim kegiatan secara tepat waktu guru sudah menunjukkan sikap profesionalismenya.

Guru yang profesional mampu mengelola waktu, mampu memahami jiwa murid-muridnya dan mempunyai keterampilan dalam memotivasi para muridnya. Guru mengirim kegiatan pembelajaran yang sesuai dengan tahapan perkembangan anak sesuai materi pembelajaran yang telah ditentukan oleh dinas pendidikan maupun kemenag.

Guru yang profesional mampu mengelola waktu, mampu memahami jiwa murid-muridnya dan mempunyai keterampilan dalam memotivasi para muridnya. Dapat di terapkan dengan cara guru mengirim kegiatan yang menarik minat sehingga para 
peserta didik bersemangat dan tertarik untuk belajar online. Melalui kegiatan yang menarik, guru dapat menumbuhkan motivasi belajar pada peserta didik.

Guru memanfaatkan teknologi kekinian dalam memberikan tugas, misalnya "membuat video tiktok cuci tangan". Self growth, guru yang profesional berupaya mengikuti perubahan agar ia dapat mencapai kualitas diri yang maksimal. Si guru ingin tumbuh dan berkembang bersama dengan murid-muridnya. Karena, perubahan zaman cepat dan guru harus ikut dalam perubahan tersebut agar tidak terjadi stagnasi. Hal ini menunjukkan bahwa guru sudah mengikuti perubahan zaman yaitu mengaplikasikan aplikasi tiktok guna menunjang proses belajar mengajar (Ahsani \& Mulyani, 2020).

Guru berusaha untuk tetap menjalankan tugasnya dengan baik, misalnya tetap mengirimkan hasil penilaian tentang peserta didik melalui email dan media social lainya seperti whatshapp grup yang sudah dibuat sebelumnya. Jadi, walaupun pembelajaran secara online, namun proses penilaian tetap berjalan. Hal ini menunjukkan ke profesionalisme seorang guru yaitu memiliki komitmen untuk meningkatkan mutu pendidikan. Walaupun pembelajaran online, guru tetap melaksanakan kewajibannya yaitu memberikan penilaian terhadap peserta didiknya.

Guru MI Hikmatun Najah berdasarkan wawancara dan data lapangan menunjukan bahwa telah menjalin komunikasi lebih intensif dengan para peserta didik. Komunikasi merupakan hal yang paling penting dalam keberhasilan pembelajaran online. Jadi, dengan melakukan komunikasi yang lebih intensif baik melalui media sosial dan bertemu langsung dengan siswa dan/atau orang tua mengingat jarak tempat tinggal yang memadai anatar sekolah, tempat tinggal dan peserta didik menunjukkan sikap keprofesionalisme seorang guru. Hal itu berarti bahwa sang guru bersungguhsungguh dalam melaksanakan kegiatan belajar mengajar melalui meskipun dilakukan pembelajaran online.

Guru yang sudah berumur hanya memberikan tugas tanpa menjelaskan materi terlebih dahulu. Hal ini menunjukkan bahwa sang guru masih belum dapat mengimplementasikan sikap keprofesionalisme mereka.

Guru memberikan materi melalui WAG (WhatsApp Group) lalu memberikan kesempatan kepada para peserta didik untuk bertanya bila mereka masih merasa kebingunan. Namun, setelah para peserta didik menyampaikan pendapat dan pertanyaan mereka sang guru justru menghilang begitu saja hingga jam pelajaran berakhir.

Berdasarkan data penelitian tersebut dapat diketahui bahwa sebagian besar guru MI Hikmatun Najah mampu mengimplementasikan sikap profesionalisme mereka melalui pembelajaran online. Sebagaimana ciri-ciri guru yang profesioanal dalam 
mengahadapi tantangan di masa pandemi saat ini yaitu, seorang guru mampu berkomitmen terhadapa proses belajar siswa di dalam sekolah, mampu menguasai tentang materi pelajaran yang akan diajarkan beserta cara mengajarkannya, serta mampu berpikir kreatif dan sistematis dari pengalaman yang telah di dapatnya(Kasful Anwar, 2015). Adapun jenis-jenis kompetensi profesional guru meliputi kecerdasan dan keahlian dalam bidangnya yaitu bahwa guru harus mampu menguasai materi yan akan diajarkan kepada peserta didiknya beserta cara mengajarkannya, guru harus mempunyai rasa tanggung jawa akan perannya sebagai guru dan rasa kebersamaan terhadap guru sejawat dan peserta $\operatorname{didik}($ Sholeh Hidayat, 2017).

Sedangkan, ada beberapa guru yang belum mampu mengimplementasikannya secara optimal dikarenakan adanya masalah jaringan internet di rumah mereka yang menyebabkan mereka masih kurang bisa aktif dalam pembelajaran online dan akhirnya mereka hilang di tengah-tengah pembelajaran online sedang berlangsung. Selain itu, bagi para guru yang sudah berumur. Mereka belum bisa beradaptasi dengan perkembangan zaman yang serba menggunakan internet. Oleh karena itu, mereka kesulitan untuk menerapkan bagaimana sikap profesionalisme seorang guru yang sesungguhnya bila pembelajaran melalui online. Sehingga mereka hanya menggunakan media pembelajaran online sebisa mereka yang akhirnya mereka hanya memberi tugas kepada para peserta didik tanpa menjelaskannya terlebih dahulu. Jadi, dapat disimpulkan bahwa meskipun ada berapa guru yg masih belum maksimal dalam kompetensi profesionalnya namun sebagian guru MI Hikmatun Najah sudah dapat mengimplementasikan sikap profesionalisme mereka melalui pembelajaran online.

\section{Simpulan}

Strategi implementasi profesionalisme guru dalam masa pandemi menjadi pusat perhatian global. Meskipun pembelajaran online ini, diharapkan para guru tetap memegang teguh kode etik mereka dan tetap bersikap profesionalisme. Mereka tidak boleh menganggap remeh pembelajaran online ini. Berdasarkan hasil penelitian uang dilakukan oleh peneliti, hasilnya menunjukkan bahwa walaupun guru MI Hikmatun Najah tidak dapat menunjukkan secara langsung sikap keprofesiolisme mereka. Namun, dengan melalui pengiriman kegiatan melalui grup kelas secara tepat waktu, guru mengirim kegiatan yang menarik minat sehingga para peserta didik tetap bersemangat dan tertarik untuk belajar online. Hal ini menunjukkan bahwa guru tetap bersikap profesional sesuai dengan keadaan, baik dalam kegiatan belajar mengajar secara face to face maupun melalui pembelajaran online. Bagi para guru yang belum mampu mengimplementasikan sikap profesionalisme dikarenakan masalah jaringan internet, 
mereka dapat mengatasinya dengan memasang jaringan wifi atau mengganti kartu internet/data seluler.

\section{DAFTAR PUSTAKA}

Abuddin Nata. (2012). Manajemen Pendidikan: Mengatasi Kelemahan Pendidikan Islam di Indonesia. Kencana.

Ahmad Susanto. (2016). Manajemen Peningkatan Kinerja Guru Konsep, Strategi, dan Implementasinya. Prenada Media.

Ahsani, E. L. F., \& Mulyani, S. E. (2020). Penerapan E-Learning Berbasis Distance Learning untuk Mengembangkan Life Skill. DIDAKTIKA: Jurnal Pendidikan Sekolah Dasar, 3(2), 115-120. https://doi.org/10.21831/didaktika.v3i2.34805

Akcaoglu, M., \& Koehler, M. J. (2014). Cognitive outcomes from the Game-Design and Learning (GDL) after-school program. Computers \& Education, 75, 72-81.

Hanik, E. U. (2020). SELF DIRECTED LEARNING BERBASIS LITERASI DIGITAL PADA MASA PANDEMI COVID-19 DI MADRASAH IBTIDAIYAH. ELEMENTARY: Islamic Teacher Journal, 8(1), 183-208. https://doi.org/10.21043/elementary.v8i1.7417

Kasful Anwar. (2015). Jaminan Mutu dan Upaya Pengembangan Profesionalitas Guru Pada Abad Pengetahuan. Nur El-Islam, 2(2), 88-105.

Kusnandar. (2007). Guru Profesional Implementasi Kurikulum Tingkat Satuan Pendidikan (KTSP) dan Persiapan Mengahadapi Sertifikasi Guru. PT Raja Gravindo Persada. https://www.google.com/search?q=Kunandar.+2007.+Guru+Profesional+Impleme ntasi+Kurikulum+Tingkat+Satuan+Pendidikan+\%28KTSP\%29+dan+Persiapan+ Mengahadapi+Sertifikasi+Guru.+Jakarta+\%3A+PT+Raja+Gravindo+Persada\%2C $+2007 . \& s a f e=$ strict $\&$ tbm $=$ bks\&sxsrf $=$ ALeKk010TRiI8YHGTYa4NV38Pbm_0bvc kA\%3A1619153123305\&ei=41CCYIGOEsDH4-

EPjqmJ2Ag\&oq=Kunandar.+2007.+Guru+Profesional+Implementasi+Kurikulum

+Tingkat+Satuan+Pendidikan+\%28KTSP\%29+dan+Persiapan+Mengahadapi+Sert ifikasi+Guru.+Jakarta+\%3A+PT+Raja+Gravindo+Persada\%2C+2007.\&gs_l=psyab.12...27549.27549.0.29215.1.1.0.0.0.0.0.0..0.0...0...1c.1.64.psyab..1.0.0...0.xMg6UqH5ZeY

Martitnis Yamin. (2007). Profesionalisasi Guru dan Implementasi KTSP. Gaung 
Persada

Press.

https://www.google.com/search?q=Martinis+Yamin.+2007.++Profesionalisasi+Gu ru+dan+Implementasi+KTSP.+Jakarta+\%3A+Gaung+Persada+Press.\&safe=strict \&tbm=bks\&sxsrf=ALeKk00m0XFTWi058eYkfj43QOnWYkOgg\%3A1619153069035\&ei=rVCCYMfJAf6N4-

EPwPeDoAo\&oq=Martinis+Yamin.+2007.++Profesionalisasi+Guru+dan+Implem entasi+KTSP.+Jakarta+\%3A+Gaung+Persada+Press.\&gs_l=psy-

ab.12...51295.51295.0.52391.1.1.0.0.0.0.296.296.2-1.1.0...0...1c.1.64.psyab..0.0.0....0.ZSAtBFOZPJo

Mu'ayyadah, M., \& Fatmawati, N. (2021). Pemanfaatan Teknologi Sebagai Pembelajaran E-Learning Google Classroom Pada Mata Pelajaran IPS. ASANKA: Journal of Social Science And Education, 2(1), 31-45. https://doi.org/10.21154/asanka.v2i1.2364

Mudhofir, A. (2012). Pendidik profesional: Konsep, strategi, dan aplikasinya dalam peningkatan mutu pendidikan di Indonesia. Raja Grafindo Persada.

Mustofa, M. (2007). Upaya pengembangan profesionalisme guru di indonesia. Jurnal Ekonomi Dan Pendidikan, 4(1), 17245.

Partono, A. R. (2020). Sikap Optimis di Masa Pandemi Covid-19. Al-Insyiroh: Jurnal $\begin{array}{lll}\text { Studi Keislaman, 6(2). } & \text {. }\end{array}$ http://ejournal.kopertais4.or.id/madura/index.php/alinsyiroh/article/view/3889/287 5

Putri, W. N., \& Nugroho, M. A. (2016). Strategi Pengembangan Profesionalisme Tenaga Pendidik di Madrasah. MUDARRISA: Jurnal Kajian Pendidikan Islam, 8(2), 313-340.

Ranak Lince. (2016). Strategi Peningkatan Profesionalisme Dalam Menghadapi Tantangan di Era Digital. Prociding.

Sholeh Hidayat. (2017). Sholeh Hidayat. Pengembangan Guru Profesional. Penelusuran Google. PT Remaja Rosada Karya. https://www.google.com/search?q=Sholeh++Hidayat.+Pengembangan+Guru+Prof esional.+\&safe=strict\&tbm=bks\&sxsrf=ALeKk00c8ubElKn_ErtMJ19PxxLp5O4A hQ\%3A1619236829647\&ei=3ZeDYP2MJ_jaz7sPn7Oc4AE\&oq=Sholeh++Hidaya t.+Pengembangan+Guru+Profesional.+\&gs_l=psyab.12...7654.7654.0.9342.1.1.0.0.0.0.614.614.5-1.1.0....0...1c.1.64.psyab..0.0.0...0.A3FuzsA6hfo

Sudarwan, D. (2012). Pengembangan Profesi Guru. Kencana. https://www.google.com/search?q=Sudarwan+Danim\%2C+Pengembangan+Profes i+Guru\&safe $=$ strict \&tbm=bks\&sxsrf=ALeKk02gRfqjnzH2Tr_NyBVTO_RWPUp HkA\%3A1619234330177\&ei=Go6DYMKqCqe_3LUPgNW6uAs\&oq=Sudarwan +Danim\%2C+Pengembangan+Profesi+Guru\&gs_l=psyab.3...17046.17046.0.18008.1.1.0.0.0.0.266.266.2-1.1.0....0...1c.1.64.psy- 
ab..0.0.0....0.Fep5DavaWSw

Suprihatiningrum, J. (2013). Guru profesional: Pedoman kinerja, kualifikasi \& kompetensi guru.

Tilaar, H. A. R. (2002). Membenahi Pendidikan Nasional. - Penelusuran Google. https://www.google.com/search?q=Membenahi+Pendidikan+Nasional.\&safe=strict \&tbm=bks\&sxsrf=ALeKk03MkNUcWmedX16jpWnryr_zZz6jg\%3A1619234749368\&ei=vY-DYLn0FZPC3LUP1-

SGqAo\&oq=Membenahi+Pendidikan+Nasional.\&gs_l=psyab.3...173286.173286.0.174344.1.1.0.0.0.0.1048.1048.7-1.1.0....0...1c.1.64.psyab..0.0.0...0.1qFizdy6gKE

Uzer, U. (2006). Menjadi Guru Profesional. PT Remaja Rosda. https://www.google.com/search?q=Uzer\%2C+Usman\%2C+M.+2006.+menjadi+G uru+Profesional $\% 2 \mathrm{C}+\mathrm{Bandung}+\% 3 \mathrm{~A}+\mathrm{PT}+$ Remaja + Rosda + Karya $\% 2 \mathrm{C} \&$ safe $=$ stric t\&tbm=bks\&sxsrf=ALeKk01NnEUTAxGMjUO4h3o1HzUxCy6KQ\%3A1619153038386\&ei=jlCCYKmMF9qe4EPkf2UkAE\&oq=Uzer\%2C+Usman\%2C+M.+2006.+menjadi+Guru+Profesional $\% 2 \mathrm{C}+$ Bandung+\%3A+PT+Remaja+Rosda+Karya\%2C\&gs_l=psyab.12...27206.27206.0.28849.1.1.0.0.0.0.120.120.0j1.1.0...0...1c.1.64.psyab..0.0.0....0.iGpQBNQn0r4

Zafi, A. A., \& Partono. (2020). Desain Pembelajaran sebagai Upaya Peningkatan Kualitas Pembelajaran al-Quran Hadis. Matan: Journal of Islam and Muslim Society, 2(1), 16-25. https://doi.org/10.20884/1.matan.2020.2.1.2292 